\title{
CUSTOMER RELATIONSHIP MANAGEMENT AS BUSINESS STRATEGY APPLIANCE: THEORETICAL AND PRACTICAL DIMENSIONS
}

\author{
Rima Tamošiūnienė, Regina Jasilionienė \\ Vilnius Gediminas Technical University, Sauletekio al. 11, LT-10223 Vilnius, Lithuania \\ E-mail: rima.tamosieniene@vv.vtu.lt
}

Received 13 September 2006; accepted 24 November 2006

\begin{abstract}
The main purpose of this article is to provide an integral and managerially useful view of customer relationship management (CRM) as business strategy. The key objectives are: to analyze CRM origins, development and changes that have occurred over time and to provide its future directions, to rank the variety of CRM definitions and determine CRM definition, which reflects CRM essence most accurately, to analyze components of CRM, to provide a framework, which ensures that CRM is approached on a strategic, balanced and integrated basis, to determine CRM strategy definition, and to identify CRM strategy position in the whole of companies strategies. The article provides best practices of CRM strategy appliance. The methods used: analysis and generalization of scientific and practical works and statistical data.
\end{abstract}

Keywords: customer relationship management (CRM), CRM strategy, relationship marketing.

\section{Introduction}

Customer Relationship Management (CRM) has become a top priority for companies seeking to gain competitive advantage in today's stormy economy. However, CRM was practiced by businesses long before IT software, even before supermarkets and automobile came along.

Over a century ago the small-town people went to their neighborhood general store to purchase goods. The proprietor and the small staff recognized the customer by name and knew the customer's preferences and wants. The customer, in turn, remained loyal to the store and made repeated purchases.

This idyllic customer relationship disappeared as the nation grew, the population moved from the farm communities to large urban areas, the consumer became mobile, and supermarkets and department stores were established to achieve economies of scale through mass marketing. Although prices were lower and goods more uniform in quality, the relationship between the customer and the merchant became nameless and faceless. The personal relationship between merchant and customer became a thing of the past. As a result, customers became fickle, moving to the supplier who provided the desired object at lowest cost or with the most features.

The last several years saw the rise of CRM as an important business approach. Its objective is to return to the world of personal relationships. The concept itself is relatively simple. Rather than market to a mass of people or firms, market to each customer individually. In this one-to-one approach, information about a customer (e.g., previous purchases, needs and wants) is used to frame offers that are more likely to be accepted. This approach is made possible by advances in information technology.

Today CRM has emerged as important business and technology initiative in many world companies across multiple industries.

Foreign practical literature devotes a lot of attention to CRM $[2 ; 4 ; 8 ; 9 ; 12 ; 13 ; 14 ; 17 ; 18 ; 20 ; 27 ; 39$; $46 ; 53 ; 54]$. Also there are plenty enough of foreign 
scientific authors who have studied different aspects of CRM $[3 ; 7 ; 15 ; 24 ; 25 ; 28 ; 34 ; 35 ; 36 ; 40 ; 41 ; 42$; $47 ; 48 ; 49 ; 55 ; 56]$.

Despite the fact that the foreign authors pay a lot of attention to CRM, in their works very fragmented aspects of CRM are researched, like CRM measurement frameworks, CRM software implementations or CRM requirements conceptualization, etc., there is a lack of integral view on basic CRM concepts.

In Lithuania it is important to assess the experiences of world countries and to make use of the current knowledge.

Practical discussions concerning CRM and CRM software implementations between Lithuanian business companies executives were started four - five years ago $[6 ; 30 ; 31 ; 32 ; 33 ; 43 ; 44 ; 45 ; 50]$. The theoretical aspects of CRM are not presented in scientific publications in Lithuania yet. CRM and CRM software implementations in Lithuanian business structures are not widely applied, although companies executives' interest to CRM solutions is high enough, especially during the last few years. Confusion reigns as to what exactly CRM is, how to implement it best, or even what role it should play in enhancing customer interaction. The other problem is that CRM means different things to different people. For some, CRM means direct e-mails. For others, it is mass customization or developing products that fit individual customers' needs. For IT consultants, CRM translates into complicated technical jargon related to terms like OLAP (on-line analytical processing) and CICs (customer interaction centers). Often executives and managers of small and midsize Lithuanian companies see CRM as technology. Even some of them have not heard about it.

A major purpose of this paper is to provide an integral and managerially useful view of the CRM as business strategy. To achieve this purpose, the following tasks were set: to research history and future of CRM approach and CRM market; to rank the variety of CRM definitions and determine CRM definition, which reflects CRM essence most accurately; to analyze components of CRM; to provide a framework, which ensures that CRM is approached on a strategic, balanced and integrated basis; to determine CRM strategy definition; to identify CRM strategy position in the whole of companies strategies; and to provide best practices of its appliance.

The article is based on the analysis and generalization of scientific and practical works and statistical data.

\section{History and Future of CRM Approach and CRM Market}

To understand the challenges facing CRM, it is important to know its origins, development and changes that have occurred over time.

In the 1980s and most of the 1990s, many enterprises cut costs, restructured and trimmed operations to achieve their financial objectives. As a result, they developed a well-practiced behavior of looking inward for answers when they had to find new ways to satisfy shareholders. This somewhat introverted behavior, while strengthening the skills of the cost cutters and internal process re-engineers, often resulted in a loss of focus on the most important reason why enterprises are in business - to satisfy customers profitably [23].

In the 1990s, a new strategic approach named relationship marketing evolved. Originating in the service or industrial marketing literature, relationship marketing focuses on the development and cultivation of long-term profitable relationships [26; 38]. Following Payne, et al. relationship marketing considers relationships "in every direction" [37].

The customer relationship management approach focuses on profit-enhancing relationships with customers $[1 ; 25]$. Based on the notion of a customer life cycle, a relationship can be seen as an investment, where, for example, customer relationship campaigns are conducted to achieve positive customer values at the end of the life cycle [5]. Depending on the different phases of the customer life cycle, recruitment, retention, and recovery, different needs of the customers occur and must be satisfied. A consideration of the special needs of customers, combined with individualized marketing campaigns, leads to higher sales [49] and increased retention of existing customers [11].

In the 1990s companies began to improve on customer relationship management by making it more of a twoway street. Instead of simply gathering data for their own use, they began giving back to their customers not only in terms of the obvious goal of improved customer service, but in incentives, gifts and other perks for customer loyalty. This was the beginning of the now familiar frequent flyer programs, bonus points on credit cards and a host of other resources that are based on CRM tracking of customer activity and spending patterns. CRM was now being used as a way to increase sales passively as well as through active improvement of customer service [46]. 
According to Chase, CRM evolved from the Sales Force Automation (SFA) market, which was in turn born of contact management [14].

Before 1993, CRM included two major markets [19]: 1) Sales Force Automation (SFA) and 2) Customer Services (CS).

SFA was initially designed to support salespersons in managing their touch points and to provide them with event calendars about their customers. SFA's meaning expanded to include opportunity management, that is, supporting sales methodologies and interconnection with other functions of the company such as production.

Compared to SFA, Customer Service (CS) is an after-sales activity to satisfy customers. The goal of CS is to resolve internal and external customer problems quickly and effectively. By providing fast and accurate answers to customers, a company can save costs and increase customer loyalty and revenue. Customer services include call center management, field service management, and help desk management.

According to Gray and Byun, today CRM involves all of the corporate functions: marketing, manufacturing, customer services, field sales, and field service, required to contact customers directly or indirectly [24]. More and more other important but less obvious functions are being linked with CRM, like order management, return materials authorization, billing, etc. [36].

Through the late 1990s and into 2000, managers plowed millions of dollars into information systems meant to track and strengthen customer relationships. Often built around complex CRM systems promised to allow companies to respond efficiently, and at times instantly, to shifting customer desires, thereby bolstering revenues and retention while reducing marketing costs. But most firms failed to reap the expected benefits, and as executives dramatically reduced IT expenses in subsequent years, CRM sales plummeted. After rising up to $28 \%$ between 1999 and 2000, CRM sales dropped by $5 \%$ in 2001, $25 \%$ in 2002, and $17 \%$ in 2003, respectively [41].

In a survey of chief technology officers organized by Infoworld in 2001, thirty percent of the CTOs agreed that CRM was the biggest blunder and most hyped technology of 2001 [15]. Many observers came to believe that CRM was destined to join enterprise resource planning (ERP) as another over-hyped IT investment whose initial unmet promise nearly killed off the approach.
But something unexpected has happened: senior executives have become considerably more enthusiastic about CRM. In 2003, Bain \& Company's annual Management Tools Survey of 708 global executives found that firms actually began to report increased satisfaction with their CRM investments. In 2001, CRM had ranked near the bottom of a list of 25 possible tools global executives would choose. Two years later, it had moved into the top half [41].

Recent Gartner surveys indicate that CRM remains a priority for more than 80 percent of large enterprises, although two-thirds have yet to see positive results from their implementations.

For 2004, the CRM software market is definitely on the upswing. Worldwide, the small and midsize business markets have seen strong growth during 2003, and indicators are that this will continue during the next five years [22].

The future of CRM looks like a complex machine [23]. The various CRM systems required and used by all organizations in the extended enterprise will combine into one collaborative environment, in which: information flows freely; customers can receive the same high level of sales and service, regardless of touch point or partner; the enterprise has a complex hierarchy of strategy, supported by metrics and tactics - which are, in turn, supported by departments and their operational systems. This will lead to the full integration of analytics, operations and infrastructure. Although this vision will not occur overnight, it will occur, regardless of business model. Industries and enterprises need to determine how to link their various systems.

Experts also predict that consumers' desire for customized interactions with a company will change customer relationship practices in general, the nature of which will be controlled by the consumer [18].

Every time a customer comes into contact with an enterprise - whether through interactions with people, a Web site, advertising campaigns or marketing materials - the customer has an opportunity to form an opinion, be it good, bad or indifferent. Over time, this collective set of customer experiences forms a picture in the customer's mind, which ultimately forms the image of the brand and its values. According to Winer, the notion of customer satisfaction is being expanded to change CRM to CEM, Customer Experience Management. The idea behind this is that with the number of customer contact points increasing all the time, it is more critical than ever to measure the customer's reactions to these contacts and develop 
immediate responses to negative experiences. These responses could include timely apologies and special offers to compensate for unsatisfactory service. The idea is to expand the notion of a relationship from one that is transaction-based to one that is experiential and continuous [55].

\section{Variety of CRM definitions}

Despite its popularity, CRM still remains an enigma for many world and Lithuanian companies. The running joke is that CRM really stands for "Customers Rarely Matter." And there are those who insist the acronym means "Can't Remember Much" — a stinging indictment for what is basically an electronic memory [52].

Many vendors, consulting firms, and even companies, build their own definition of CRM partially mindful of how others are defining the term. This is largely because company executives, functional managers, software vendors, industry analysts and management consultants hold myriad views on CRM, each shaped by their given position, situation, experience and motives [36].

While definitions are diverse, the market seems to have coalesced along three "kinds" of definitions: 1) technology centric, 2) customer lifecycle centric, 3) strategy centric [29].

1. Technology centric definitions of CRM evolve out of the need for vendors to position their particular product, which often automates just a portion of the CRM problem, in the best or broadest possible light. Authors of these definitions make the connection between the preceding technologies, such as back-end and front-end systems, and CRM (13; 16; 40; 55]. These links tend to be tenuous and not a single-direct path towards CRM [7]. For example, Burghard and Galimi state, that CRM is an IT driven concept used to design the business and its processes around the customers' wants and needs [12].

With investment in CRM technologies remaining at very high levels, it is no wonder the conversation gravitates to the technological and practical mechanics of CRM. And given that today we see such a complex and wide range of customer-facing, customer touching and customer intelligence applications to enable CRM, this is an understandable and necessary perspective. However, this perspective does not reflect the essence of CRM as a whole.

2. Customer lifecycle definitions evolve out of the need for CRM practitioners to describe a new busi- ness capability, or a new arrangement of capabilities, that focuses on the customer lifecycle, not the product lifecycle. The customer lifecycle, often described somewhat differently, has four phases: (1) attracting, (2) transacting, (3) servicing and supporting, (4) enhancing [29]. In the attraction phase, a customer becomes aware of the product or company, develops interest and tries to understand the product or company. In the transacting phase, the customer has moved to the next level of commitment and decided to procure a product or service. In the service and support phase, the customer requires the company's assistance in installing, using or servicing of what was procured. In the enhancement phase, the customer may be thinking about purchasing additional products or services. For the majority of companies, especially larger ones, the parts of the companies that interact with the customer throughout this lifecycle are separated from each other and not optimally coordinated or integrated. The customer lifecycle definition of CRM often describes CRM as the ability to seamlessly interact with or market to the customer throughout this lifecycle.

3. Strategy centric definitions look primarily to free the term CRM from any technology underpinnings and to a lesser extent from specific customer management techniques. These definitions describe CRM as a technique to compete successfully in the market and build shareholder value. CRM represents a fundamental shift in the way many companies do business. This change in perspective has ridden, or quite possibly driven, a greater paradigm shift in global business: the migration from product- to customer-centricity.

Most consulting firms and industry research analysts espouse this perspective on CRM. They suggest to organizations to recognize that the achievement of longterm value from CRM is dependent upon embracing it as a strategy involving the whole business, requiring them to approach it at an enterprise level [36].

According to Gartner definition, CRM is a business strategy designed to optimize profitability, revenue and customer satisfaction by organizing the enterprise around customer segments, fostering customer-centric behaviors and implementing customer-centric processes [23]. Gartner emphasizes, that CRM is not as a category of applications or technologies, although technologies are critical to enabling CRM strategies.

L. Brown and J. Gravely state, that CRM is a business strategy which is focused on maximizing shareholder value through winning, growing, and keeping the right customers. It employs practices, methodologies, software, and Internet capabilities that help an enterprise manage customer relationships in an organ- 
ized way. As a business strategy, CRM helps a company stay focused on delivering the best services and products to the appropriate target customer. It enables any representative of a company, either a sales representative or a service person, to remember who they are talking to, no matter what the transaction might be [10].

In this study we have applied strategy centric viewpoint of CRM, because this definition of CRM most accurately captures the present day sentiment and mindset, which favors a view of CRM that is broad and strategic.

\section{Components of CRM}

CRM consists of three components [24]: 1) customer, 2) relationship, and 3) management (Fig 1).

Customer: the customer is the only source of the company's present profit and future growth. However, a good customer, who provides more profit with less resource, is always scarce because customers are knowledgeable and the competition is fierce. Sometimes it is difficult to distinguish who is the real customer because the buying decision is frequently a collaborative activity among participants of the decision-making process [56]. Information technologies can provide the abilities to distinguish and manage customers.

Relationship: the relationship between a company and its customers involves continuous bi-directional communication and interaction. The relationship can be short-term or long-term, continuous or discrete, and repeating or one-time. Relationship can be attitudinal or behavioral.

Even though customers have a positive attitude towards the company and its products, their buying behavior is highly situational [56]. For example, the buying pattern for airline tickets depends on whether a person buys the tickets for their family vacation or a business trip.

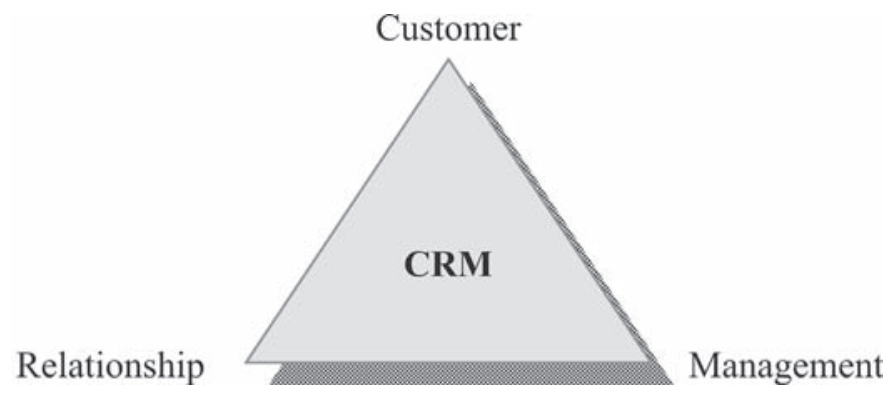

Fig 1. Components of CRM [24]
According to the type of client with which relationships are maintained, the following CRM relationship types can be stated:

1. B2C (Business-to-Consumer) - a form of relationship conducted between businesses and consumers. B2C relationship includes both formal relationships (for example, customers with subscription based services or content) and ad hoc relationships (formed in real time to enable a new user to buy, sell or access information). B2C CRM is all about creating business value and improving customer relationships.

2. B2B (Business-to-Business) - a form of relationship conducted among businesses, typically because of formal, contractual arrangements. In e-commerce, B2B functions include: (a) sophisticated Web authorization and control for delivery of sensitive price, contract and content information for each partner; (b) catalogs that provide custom views based on access controls and parametric searches; (c) order entry functions such as standardized "ship to" locations, dynamic order recalculation and payment options [23].

3. B2B2C (Business - to - Business - to -Consumer) - a form of relationship in which businesses (e.g. enterprises of insurance, banking, brokerage, consumer goods, automotive and pharmaceutical industries) sell products to consumers through other, "channel partner" businesses, such as distributors, retailers and brokers.

CRM involves managing these relationships so they are profitable and mutually beneficial. Customer lifetime value (CLV), is a tool for measuring these relationships.

Management: CRM is not an activity only within a marketing department, rather it involves continuous corporate change in culture and processes. The customer information collected is transformed into corporate knowledge that leads to activities that take advantage of the information and of market opportunities. CRM required a comprehensive change in the organization and its people.

\section{CRM Generational Framework}

To achieve the long-term value of CRM, enterprises must understand that it is a strategy involving the whole business, and therefore should be approached at an enterprise level.

Many world and Lithuanian enterprises still attempt to implement CRM as a series of unintegrated, departmental projects - but this is not "true CRM," 
and will not yield benefits or long-term value for the enterprise.

CRM requires board-level vision and leadership to drive a relentless focus on the customer; otherwise, it will remain fragmented. It involves potentially difficult changes of processes, culture and organization. Technology staff must grapple with the challenges of multichannel alignment, system integration and data quality.

CRM initiatives need a framework to ensure that programs are approached on a strategic, balanced and integrated basis. Gartner Inc. has developed such a framework, called the Eight Building Blocks of CRM. Just as a road map helps understand the context of a journey, this CRM framework is designed to help enterprises make decisions about the best route and objectives, given in their situation [23].

Successful CRM requires expertise in the following eight areas (each of which serves as one of the eight "building blocks" in the Gartner framework):

1. Vision - creating a picture of what the customer - centric enterprise will look like, in order to build a competitive market position based on value propositions that are defined, communicated and personified by the enterprise brand.
2. Strategy - developing a strategy to turn the customer base into an asset by delivering customer value propositions. This includes setting objectives and determining how resources will be used to interact with customers.

3. Valued Customer Experience - ensuring that the enterprise's offerings and interactions deliver ongoing value to customers, are delivered consistently and achieve the desired market position.

4. Organizational Collaboration - changing cultures, organizational structures and behaviors to ensure that employees, partners and suppliers work together to deliver customer value.

5. Processes - effectively managing not only customer lifecycle processes (for example, welcoming new customers, handling inquiries and complaints, and winning back lost customers), but also analytical and planning processes that build knowledge of the customer.

6. Information - collecting the right data and routing it to the right place.

7. Technology — managing data and information, customer-facing applications, IT infrastructure and architecture.

\begin{tabular}{|c|c|c|c|c|c|}
\hline \multirow{2}{*}{$\begin{array}{l}\text { CRM } \\
\text { Building } \\
\text { Block: } \\
\qquad \text { Vision }\end{array}$} & \multicolumn{5}{|c|}{ Generation: } \\
\hline & None & $\begin{array}{l}\text { Initial } \\
\text { productivity } \\
\text { and visibility }\end{array}$ & $\begin{array}{c}\text { Function/ } \\
\text { channel } \\
\text { effectiveness }\end{array}$ & $\begin{array}{l}\text { Intraenterprise } \\
\text { integration }\end{array}$ & $\begin{array}{l}\text { Value-network- } \\
\text { enabled }\end{array}$ \\
\hline \multirow[b]{3}{*}{$\begin{array}{l}\text { Organizational } \\
\text { Collaboration }\end{array}$} & None & $\begin{array}{l}\text { Isolated projects, } \\
\text { initiated from } \\
\text { the bottom up }\end{array}$ & $\begin{array}{l}\text { More "joined up" } \\
\text { thinking, but still } \\
\text { silo-oriented }\end{array}$ & $\begin{array}{l}\text { Enterprise-level } \\
\text { CRM program }\end{array}$ & $\begin{array}{l}\text { Value-based } \\
\text { collaboration for } \\
\text { mutual benefit }\end{array}$ \\
\hline & $\begin{array}{l}\text { Unknown concept; } \\
\text { designs itself }\end{array}$ & $\begin{array}{l}\text { Unknown concept; } \\
\text { designs itself }\end{array}$ & $\begin{array}{l}\text { Understanding and } \\
\text { focus at silo level }\end{array}$ & $\begin{array}{l}\text { Cross-LOB } \\
\text { understanding } \\
\text { and focus }\end{array}$ & $\begin{array}{l}\text { Understanding of } \\
\text { wider scope; } \\
\text { collaboration }\end{array}$ \\
\hline & $\begin{array}{l}\text { Inward focus; } \\
\text { silo structures }\end{array}$ & $\begin{array}{l}\text { First signs of } \\
\text { customer } \\
\text { centricity; silos }\end{array}$ & $\begin{array}{l}\text { Changing culture } \\
\text { and incentives; } \\
\text { silos }\end{array}$ & $\begin{array}{l}\text { Customer-centric; } \\
\text { reorganized by } \\
\text { segment }\end{array}$ & $\begin{array}{l}\text { Shared customer } \\
\text { centricity; } \\
\text { goal alignment }\end{array}$ \\
\hline Processes & $\begin{array}{l}\text { Inward focus; } \\
\text { silo-oriented }\end{array}$ & $\begin{array}{l}\text { Start optimizing } \\
\text { for efficiency; } \\
\text { silo-oriented }\end{array}$ & $\begin{array}{l}\text { Optimization at } \\
\text { silo level for cost } \\
\text { and value reasons }\end{array}$ & $\begin{array}{l}\text { Enterprise-level } \\
\text { optimization for } \\
\text { cost and value }\end{array}$ & $\begin{array}{l}\text { True end-to-end } \\
\text { process } \\
\text { optimization }\end{array}$ \\
\hline Information & $\begin{array}{l}\text { Basic and } \\
\text { fragmented }\end{array}$ & $\begin{array}{l}\text { Team-based; } \\
\text { fragmented; } \\
\text { minimal insight }\end{array}$ & $\begin{array}{c}\text { Shared information } \\
\text { at silo level; insight } \\
\text { developing }\end{array}$ & $\begin{array}{l}\text { Shared information } \\
\text { and insight across } \\
\text { the enterprise }\end{array}$ & $\begin{array}{l}\text { Shared information } \\
\text { and insight beyond } \\
\text { the enterprise }\end{array}$ \\
\hline Technology & $\begin{array}{l}\text { Very fragmented; } \\
\text { weak functionality }\end{array}$ & $\begin{array}{l}\text { Fragmented; } \\
\text { limited functionality } \\
\text { and focus }\end{array}$ & $\begin{array}{l}\text { Strong } \\
\text { functionality } \\
\text { within silos }\end{array}$ & $\begin{array}{l}\text { Strong functionality } \\
\text { with enterprise- } \\
\text { level integration }\end{array}$ & $\begin{array}{l}\text { Strong functionality; } \\
\text { integrated beyond } \\
\text { the enterprise }\end{array}$ \\
\hline Metrics & $\begin{array}{l}\text { Few metrics; } \\
\text { inward focus }\end{array}$ & $\begin{array}{l}\text { Fragmented and } \\
\text { limited metrics; } \\
\text { operational focus }\end{array}$ & $\begin{array}{l}\text { Focus on silo } \\
\text { efficiency; lack of } \\
\text { customer focus }\end{array}$ & $\begin{array}{l}\text { Enterprise-and } \\
\text { customer-focused; } \\
\text { balanced hierarchy }\end{array}$ & $\begin{array}{c}\text { Shared objectives } \\
\text { and balanced } \\
\text { metrics; aligned }\end{array}$ \\
\hline Source: Gartner & & & & $\begin{array}{l}\text { CRM customer rela } \\
\text { LOB line of busine }\end{array}$ & $\begin{array}{l}\text { tionship management } \\
\text { ss }\end{array}$ \\
\hline
\end{tabular}

Fig 2. Gartner CRM Generational Framework [23] 
8. Metrics - measuring internal and external indications of CRM success and failure.

As Gartner states, in each of these building blocks, different enterprises will have progressed to different levels. These differences are normal (and appropriate), because CRM should represent a continuous process, not a one-time initiative. Therefore, enterprises need to understand where they are and where they are heading. Fig 2 shows a generational framework for each of the eight building blocks.

Few enterprises align in a single generation across all building blocks. Instead, they tend to have several in a particular generation, one or two that are one generation ahead, and one or two that lag by a generation. Gartner states that enterprises should not worry about perfect alignment by generation. Instead, they should focus on understanding where they are and where they are going with regard to each building block.

Enterprises that are more than one generation off (either forward or behind) in a particular building block, however, may have an out-of-balance CRM strategy that needs careful examination. For example, a sophisticated, fourth generation strategy will not work if customer information remains basic and fragmented (level 1) [23].

\section{Grades of Strategy and CRM Strategy Fit}

CRM strategy cannot stand alone; it must be derived from corporate strategy, goals and imperatives, and it must be linked to other strategies. According to Moses, the most typical and recognizable grades of strategy include (see Fig 3): 1) Corporate Strategy,

2) Business Strategy, 3) Functional Strategy, and

4) Organizational Strategy [36].

The area of corporate strategy answers the question, "What business should I be in?" and generally in- volves efforts around industry participation, geographic presence, portfolio management, mergers and acquisitions.

Once a corporation understands what businesses and markets it wants to participate in, it must answer the question (area of business strategy), "How do I compete?" This question can be further broken down into two complementary parts, "How do I beat the competition?" and "How do I win the customer?" In large companies, these questions are usually answered on a business unit level rather than a corporate level.

Once a company or business unit determines a goto-market strategy that establishes its industry position and market presence, it must answer the question (area of functional strategy), "How do I operate?" in order to fulfill the business strategy. This involves all of the complex decisions on processes, techniques and tools, among other things, that will render the business strategy.

Once a company knows what it is designed to do and how it will do it, it can begin to answer the question (area of organizational strategy), "How should I organize my resources?" This primarily includes decisions on aligning human and financial capital in the best way to fulfill the functional strategy.

Naturally each of these grades of strategic thought is interdependent. The efficacy of a company's strategy demands synergy between them all. Therefore, it is most desirable to establish a natural cascade from one higher level to the next lowest. Of course in reality, there may be an upward influence, where decisions at a lower grade may affect what a company decides at a higher grade.

Moses states, that CRM strategy is generally accepted as a form of "functional" or "operational" strategy (Grade 3), as it introduces a flood of possibilities for new tactics and tools to improve operations. But the key point is to recognize that a company should not

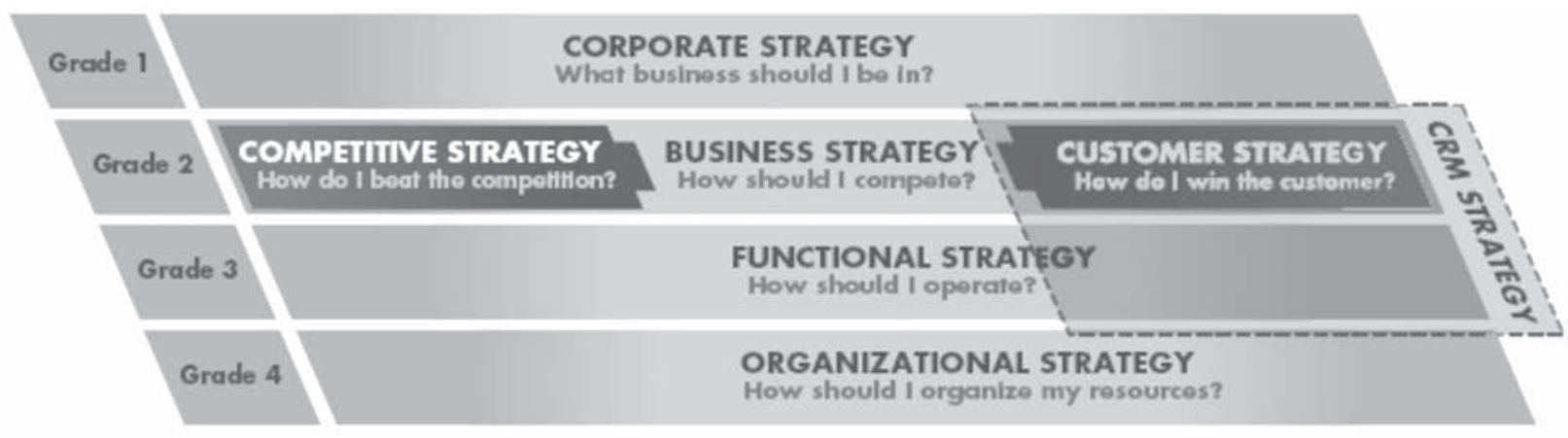

Fig 3. Grades of Strategy and CRM Strategy Fit [36] 
construct or implement CRM in isolation. It is critical to understand CRM's co-dependence on other grades in order to generate the best outcomes.

\section{CRM Strategy Appliance}

CRM strategy is the set of activities a business performs to confirm and render its customer strategy, focusing on the identification, prioritization and implementation of new customer-facing business capabilities and practices that will improve operations and segment profitability [36].

CRM strategy guides how an enterprise turns customers into assets, beginning with an understanding of current customers and how they relate to the market. For the reason that fewer than 15 percent of enterprises understand this relationship, most skip this vital planning step.

The following four strategies help to make CRM work [23]:

1. Extend the depth and breadth of relationships to get a larger share of the customer relationship. Assume that the enterprise is underrepresented in the customer's thinking, and that it can enlarge its "fair share" of the relationship.

2. Reduce transaction barriers and costs. Move customers and transactions from high-cost channels to low-cost ones, such as the Web.

3. Reinforce the brand. CRM fulfills the promise created around the brand. This strategy emphasizes the handoff from branding media (for example, television) to more interactive media (for example, the call center).

4. Create customer satisfaction and loyalty. The goal is happier customers. An enterprise needs to approach every interaction with the customer as an opportunity to create customer satisfaction.

As no single strategy works for everyone, an enterprise should not limit itself to just one. Although an enterprise should work on all four strategies simultaneously, one strategy will end up dominating, based on the goals and culture of the enterprise.

An enterprise should consider the following best practices when aligning its CRM strategy $[14 ; 23 ; 34 ; 39$; 51; 52]:

- Engage the CEO, business and technology strategists, and key executives from functions such as marketing, human resources, sales and customer service.

- Define CRM as an enterprise-level initiative (al- though implementation of the strategy may start at the departmental level). Organizations should have very clear business objectives for their CRM initiatives and this clarity can only emerge from a well thought-out and well-documented CRM vision. Though formulating a solid CRM vision is a formidable challenge, it is just the first of many challenges at this stage of the game.

- Ensure that the enterprise and marketing strategy are in place, and that target customers have been well defined.

- Name a CRM executive sponsor and define his or her role. Executive sponsorship ensures that the project has high visibility and buy-in among all ranks of users. A CRM solution impacts many departments and if done right requires changes in business processes. For these changes to be effective the executive sponsors need to drive the adherence to the changes within their departments.

Gartner Inc. suggests to use the following six-step methodology to develop a CRM strategy: 1) Audit the enterprise's current position with customers, and in the market; 2) Segment the customer base, and identify target segments; 3) Set customer objectives (such as acquisition, development or retention) for each market objective; 4) Define metrics for monitoring the execution and evolution of the strategy; 5) Outline, by segment, the strategy to customize products, pricing, communication and channels - and to manage customer service and contacts - in order to create the desired customer value proposition and customer experience; 6) Specify the required customer capabilities and infrastructure (such as people, IT and data) [23].

\section{Conclusions}

In the past in the most world and Lithuanian companies the emphasis has been wrongly placed on CRM software choices and implementation plans, not on CRM strategies building. Companies' executives have foregone some of the most basic disciplines and failed to address the simplest questions when embarking on such a critical CRM venture. To achieve the long-term value of CRM, enterprises must understand that it is a strategy involving the whole business, and therefore should be approached at an enterprise level.

There is no "one size fits all" business strategy to a successful CRM initiative, but there are common "rules of the road" that are essential to CRM success. Enterprises need to understand what CRM really is, how to approach it, what CRM means to the busi- 
ness and its customers, and how to entice customers and gain market share.

CRM success requires effective change of management, strong leadership and governance, measurement of results, tight integration of technologies and a process based approach to solving problems.

\section{References}

1. AHLERT, D.; HESSE, J. Relationship Management im Beziehungsnetz zwischen Hersteller, Haendler und Verbraucher. Customer Relationship Management im Handel. Berlin, 2002, p. 3-30.

2. AMERONGEN, T. Hitting the Mark with CRM. 2004. URL: http://www.ifusioncrm.com.

3. BAUMEISTER, H. Customer Relationship Management for SME's. E2002, Prague, p. 16-18.

4. BEASTY, C. SMBs Are Upping Tech Spending. CRM Magazine, 2005, Vol 9, Issue 8, p. 19.

5. BECKER, J.; DREILING, A.; HOLTEN, R., et al. Specifying Information Systems for Business Process Integration - a Management Perspective. Information Systems and E-Business Management, 2003, Vol 1, p. 231-263.

6. BOGATYRIOVA, A. Kiekvienas klientas - svarbiausias. Vadovo pasaulis, 2001, Nr. 11, URL: http:// verslas.banga.It

7. BOON, O.; CORBITT, B.; PARKER, C. Conceptualising the requirements of CRM from an organisational perspective: a review of the literature. In 7th Australian Workshop on Requirements Engineering AWRE'2002, 2-3 December, 2002, Melbourne, Australia.

8. BORDOLOI, Ch. CRM Projects: A Framework for Success. 2002. URL: http://crm.ittoolbox.com.

9. BREU, C.; MECKL, N.; SAMETINGER, J. ProjectBased Customer Relationship Management in Virtual Enterprises. 2001. URL: http://crm.ittoolbox.com.

10. BROWN, L. and GRAVELY, J. Special Edition Using Microsoft CRM. Que, 2003. 640 p.

11. BUCHANAN, R.; GILLES, C. Value Managed Relationship. The Key to Customer Retention and Profitability. European Management Journal, 1990, Vol 8 (4), 1990, p. 523-526.

12. BURGHARD, C.; GALIMI, J. Customer Relationship Management - New MCO Catalyst. Gartner Advisory, 2000.

13. CHANG, J. CRM Suites for Medium to Large Enterprises. The Customer Relationship Management Solutions Guide. 3rd Edition. 2001. URL: www. crmguru.com.

14. CHASE, P. Why CRM implementations fail. 2001. URL: http://www.dmreview.com.

15.DAY, G.; BULTE, C. Superiority in Customer Re- lationship Management: Consequences for Competetive Advantage and Performance. 2002.50 p. URL: http://crm.ittoolbox.com.

16. DAY, G. Managing Market Relationships. Journal of the Academy of Marketing Sciences, 2000, Vol 28, No 1.

17. DICKIE J. What's Hot, What's Not, and What's Next. CRM Magazine, 2005, Vol 9, Issue 12, p. 22.

18. ENRIGHT, A. CRM / customer relations. Marketing News / OUTLOOK 2006, Jan 15, 2006, p. 13-14.

19. Financial Times. Financial Times Surveys Edition, June 7, 2000, p. 25.

20. FIRTH, D. The Organizing Vision for Customer Relationship Management. 2001, 8 p. URL: http:// crm.ittoolbox.com.

21. GARTNER, Inc. CRM Growth Change. VARBusiness, 12/5/2005, Vol 21, Issue 26, p. 54-54.

22. GARTNER, Inc. Market Trends: CRM Software, Worldwide. 11 January, 2005. 26 p.

23. GARTNER, Inc. Reaping Business Rewards From CRM: From Charting the Vision to Measuring the Benefits. Gartner Press, 2004. 368 p.

24.GRAY, P.; BYUN, J. Customer Relationship Management. March, 2001. 57 p. URL: http:// crm.ittoolbox.com.

25. GREENLEAF, E.; WINER, R. Putting the Customer Back into Customer Relationship Management (CRM). Advances in Consumer Research, 2002, Vol 29 (1), p. 357-360.

26. GROENROOS, C. From Marketing-Mix to Relationship Marketing. Towards a Paradigm Shift in Marketing. Management Decisions, 1994, Vol 28 (2), p. 4-20.

27. YOUNGER, J.; TROCHLIL, W. Customers at the Core. Association Management, 2004, Vol 56, Issue 12, p. 57-60.

28. KAMAKURA, W.; MELA, C.; ANSARI A., et al. Choice Models and Customer Relationship Management. Marketing Letters. December, 2005, Vol 16, p. 279-291.

29. KELLEN, V. CRM Measurement Frameworks. 2002. URL: http://crm.ittoolbox.com.

30. KIRVAITIS, A. CRM - ginklas kovoje dèl vartotoju ištikimybés. 2002. URL: http://www.mdc.lt.

31. KIRVAITIS, A. CRM iššūkis: veidu ì klientą. 2002. URL: http://www.ebiz.lt.

32. Kirvaitis A. CRM: prieš starta - ka reikia padaryti, prieš pradedant $\mathrm{ka}$ nors daryti. 2002. URL: http:// www.ebiz.lt.

33. KUPRYS, M. Klientu valdymas ir pardavimai, paremti CRM strategija. 2002. URL: http:/www.ebiz.lt.

34. McALLISTER, T. A. Customer Relationship Management - A Case for e-Business Strategy. 2002. 47 p. URL: http://crm.ittoolbox.com. 
35. MILLARD, N. A million segments of one - how personal should customer relationship management get? BT Technology Journal, 2003, January, Vol 21, p. 114-120.

36. MOSES, J. D. Can Strategy Save CRM? 2005, 22 p. URL: http://www.inforte.com

37.PAYNE, A.; CHRISTOPHER, M.; CLARK, M.; PECK, H. Relationship Marketing for Competitive Advantage - Winning and Keeping Customers. Butterworth-Heinemann, Oxford, U.K. et al., 1998.

38.PECK, H.; PAYNE, A.; CHRISTOPHER, M.; CLARK, M. Relationship Marketing: Strategy and Implementation. Butterworth-Heinemann, Oxford, U. K. et al., 1999.

39. RAMDAS, N. Planning for a Successful CRM Initiative. 2003. URL: http://crmlibrary.crmcommunity.com.

40. RENNER, D. Closer to the Customer: Customer Relationship Management and the Supply Chain. Montgomery Research Inc., 1999, Vol 1, URL: www.ascet.com/documents.asp?d_ID $=210$.

41. RIGBY, D.; LEDINGHAM, D. CRM Done Right. Harvard Business Review, 2004, Vol 82, Issue 11, p. 118-129.

42. RIGBY, D.; REICHHELD, F.; SCHEFTER, P. Avoid the four perils of CRM. Harvard Business Review. 2002.

43. RYTEL, T. CRM - vaistas nuo bankroto? 2002. URL: http://www.ebiz.lt.

44. RYTEL, T. CRM plètojimo problemos. 2002. URL: http://www.ebiz.lt.

45. RYTEL, T. Praktiniai patarimai diegiantiems CRM. 2002. URL: http://www.ebiz.lt.

46. ROBERTS, L. P. The History of CRM - Moving Beyond the Customer Database. 2004. URL: http:// EzineArticles.com.
47. ROMANO, N.; FJERMESTAD, J. Electronic Commerce Customer Relationship Management: A Research Agenda. Information Technology and Management. April, 2003, Vol 4, p. 233-258.

48. STARKEY, M.; WOODCOCK, N. CRM systems: necessary, but not sufficient. REAP the benefits of customer management. The Journal of Database Marketing, March, 2002, Vol 9, No 3, p. 267-275.

49.STONE, M.; WOODCOCK, N.; WILSON, M. Managing the Change from Marketing Planning to Customer Relationship Management. Long Range Planing, 1996, Vol 29 (5), p. 675-683.

50.SVARAVIČIUS, A.; BALIUKEVIČIUS, A. Verslo valdymo ateitis priklauso CSRP klasès informacinems sistemoms. 2001. URL: http://www.elsis.lt.

51.TAMOŠIŪNIENĖ, R.; JASILIONIENĖ, R. Challenges of CRM software implementations in Lithuania. In Scientific Proceedings of the Scientific-Technical Union of Mechanical Engineering. June, 2005, Vol 2 (80), p. 139-142.

52.TYNAN, D. The 10 Biggest CRM Mistakes. Sales \& Marketing Management. December, 2005, Vol 157, Issue 12, p. 30-33.

53. WIKSTROEM, C. Organizational Change and Customer Relationship Management Success. 2003. URL: http://crm.ittoolbox.com.

54. WILKERSON, L. How CRM Software Works - Creating Customer Satisfaction with a Click. 2004. URL: http://EzineArticles.com

55. WINER, R. S. Customer Relationship Management: A Framework, Research Directions, and the Future. 33 p. 2001. URL: http://crm.ittoolbox.com.

56. WYNER, G. A. Customer Relationship Measurement. Marketing Research, 1999, Vol 11, No 2, p. 39-41. 